\title{
APPLICATION OF EUROPEAN UNION'S CULTURAL INDICATORS OF SUSTAINABLE TOURISM - A CASE STUDY OF BELGRADE
}

\author{
Dobrila Lukići*, \\ Aleksandar Joksimović \\ ${ }^{1}$ Eight Belgrade Grammar School, \\ Belgrade, Serbia \\ ${ }^{2}$ Alfa BK University, \\ Belgrade, Serbia
}

\begin{abstract}
:
Comparative tourism sustainability indicators created by the European Union provide a basis for assessing the degree of sustainability of tourism development in a given area. They are divided into five groups, namely economic indicators, social indicators, cultural indicators, tourist satisfaction and state of the environment indicators. Coding is used to determine threshold values for each indicator, while the state of tourism is assessed as critical, bearable or sustainable and thus classified in the red, yellow or green zone, respectively. This paper analyses the cultural indicators of sustainable tourism in Belgrade, which are then used to determine the preservation of cultural identity of the local population with respect to the impact of tourists. Relevant statistical data about Belgrade in the period 2010-2019, recorded by the Statistical Office of the Republic of Serbia, were used for the purpose of this paper, specifically the data on accommodation capacities and tourist turnover, as well as data on the size of the population from the last census carried out in 2011. Based on those data, values were obtained concerning the ratio of accommodation capacities and the size of the local population and tourism intensity, as cultural indicators representing a starting point for taking necessary administrative measures and actions in tourism in Belgrade.
\end{abstract}

Keywords:

EU cultural comparative indicators, sustainable tourism, Belgrade, Serbia.

\section{INTRODUCTION}

The continuous development of mass tourism has created a need to place that activity under the umbrella of sustainable development in order to preserve tourism potentials for future generations. Sustainable tourism entails the economic development of the local community, but in such a way that it contributes to the preservation of environmental protection. The European Union indicators of sustainable tourism are divided into five categories. Those are: economic indicators, tourist satisfaction, cultural indicators, social indicators and state of the environment indicators. The indicators serve to show the current state and possible development of tourism in a given destination in terms of sustainable development as well as the impact of tourism on economic, socio-cultural and environmental aspects of the destination (Ceron \& Dubois, 2003).
Correspondence:

Dobrila Lukić

e-mail:

dobriladjerdap@gmail.com

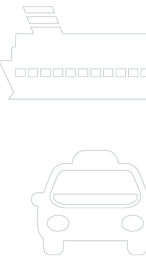


Economic indicators show the economic effects of tourism development in a destination. Tourist satisfaction is the degree of satisfaction with the quality of the environment and the attraction of tourist motives, sociocultural characteristics of the destination and the quality of provided services and accommodation facilities. Social and cultural indicators reflect the degree of social and cultural integrity of the local community under the influence of tourists, while environmental indicators show the impact of tourism on water resources, air, land and the diversity of flora and fauna in the destination. Each indicator has threshold values and the state of tourism is assessed as critical, bearable or sustainable, which is why these indicators are also referred to as "warning" indicators (Ko, 2005). Based thereon, three zones are defined for each indicator. Specifically, the red zone, in which the situation is assessed as critical, requiring appropriate measures to be taken for modifying the further development and control of tourism. The yellow zone indicates that the situation is bearable and any serious problems that may arise in the future could be contained by taking pre-emptive action. Finally, the green zone denotes that tourism development in a given destination is sustainable due to good management and imposing appropriate measures and activities (Jovičić, 2000; Pavlović \& Belij, 2012)

\section{THE EUROPEAN UNION'S INDICATORS OF SUSTAINABLE TOURISM}

Tourism destinations are the focal point of tourism activity. Eurostat data shows that in 2014, Europeans made more than one billion tourism trips, spending in total EUR 391 billion or an average of EUR 334 per trip. Responsible destination management therefore plays an essential role in ensuring that European tourism destinations are viable in the long run, which, in other words, requires implementation of the European Tourism Indicator System (ETIS) representing a common methodology towards sustainable destination management (European Commission, 2016). The ETIS was launched by the European Commission as an effective management tool, specially designed for tourist destinations to monitor performance and help destinations to develop and carry out their plans for enhanced sustainability with a long-term vision. In view of that, in order to secure continuous improvements in a destination, steps should be taken to raise awareness and engage all stakeholders, define responsibilities, collect data and analyse results. A key step in that regard is forming an interdisciplinary team consisting of all stakeholders tasked with establishing priorities, roles and responsibilities among players, stimulating cooperation and coordination and supporting management and monitoring process (European Commission, 2016).

The European Union's indicators of sustainable tourism are a set of 43 core and supplementary indicators that can be used in their entirety or integrated into existing destination-monitoring systems. Destinations are free to choose themselves the most relevant indicators they wish to adopt and monitor in order to meet their respective needs together with the sustainability issues each destination faces. The fundamental principle of the indicator system is that destination decision-making, ownership and responsibility is shared. The core indicators represent baseline information that a destination needs to understand, monitor and manage its performance. The core indicators cover the basic sustainability aspects and provide the basis for effective destination management, allow for comparison in one destination over time and for benchmarking between a number of destinations (European Commission, 2016). Supplementary indicators allow destinations to tailor the system to their own particular needs or destination category, e.g. mountain, city, rural, coastal areas, or macro-regional and transnational dimensions. Such supplementary indicators must be tested and provided with a clear methodology if they are to be used by other destinations (European Commission, 2016).

\section{BELGRADE AS A TOURIST DESTINATION}

If compared to other tourist cities in the region, Belgrade, the capital of Serbia, can take the advantages of the cordiality and hospitality of its residents, delicious food, its geographical location, rich history, lower living standard, good knowledge of foreign languages of its residents and Serbia's good relations with both Western and Eastern countries, which enlarges the tourism market considerably. New opportunities for the development of Belgrade as a tourist destination are reflected in its unique location at the confluence of two major rivers, the passage of international road and river corridors through its territory and airport expansion, 
which creates new opportunities for tourism development. Belgrade has a very rich cultural and historical heritage as the most conquered, bombarded and destroyed city in Europe as well as because of civilisations and peoples that used to live there. The establishment of a visa-free regime for the citizens of Russia and China is an enormous potential for development of tourism given the size of those two markets. A large number of visitors from Israel, Greece, China and Turkey indicate that Belgrade attracts tourists from different parts of the world. Considering that the standard of living in Serbia is lower than in developed countries, Belgrade also has the advantage of being less costly than for instance Budapest or Sophia, which is yet another factor that influences the selection of a destination. Many studies on tourist satisfaction with Belgrade report that tourists who visit Belgrade for the first time would visit it again, meaning that they feel comfortable and secure in it, which is a prerequisite for successful development of tourism (Panić, 2018).

\section{METHODOLOGY}

The subject of this research is tourism in the territory of the City of Belgrade, analysed through the prism of the European Union cultural indicators with the aim of determining the state of destination sustainability. Cultural indicators show the impact of tourists coming from areas with different cultural characteristics on the degree of preservation of the local community's cultural identity. This group of indicators includes the ratio of accommodation capacities to the size of the local population and tourism intensity, representing the ratio between the number of overnight stays during a year expressed in thousands and the size of the local population expressed in hundreds (Miller, 2001; Stojanović, 2006). If both indicators exceed the ratio of 1.6:1, the domicile population is under intense pressure from tourism development, meaning that tourism is far from sustainable and is classified in the red zone. Destinations with values under 1.1:1 are classified in the green zone, i.e. have sustainable development of tourism, while those with values ranging between 1.1:1 and 1.5:1 belong in the yellow zone (Table 1) (Jovičić \& Ilić, 2010).

Table 1. CULTURAL INDICATORS OF SUSTAINABLE REGIONAL TOURISM DEVELOPMENT

\begin{tabular}{|c|c|c|}
\hline \multirow{6}{*}{$\begin{array}{l}\text { Cultural } \\
\text { indicators }\end{array}$} & \multirow{3}{*}{$\begin{array}{l}\text { Ratio of accommodation capacities } \\
\text { to the size of local population }\end{array}$} & $<1.1: 1$ green zone \\
\hline & & $1.1-1.5: 1$ yellow zone \\
\hline & & $>1.6: 1$ red zone \\
\hline & \multirow{3}{*}{ Tourism intensity } & $<1.1: 1$ green zone \\
\hline & & $1.1-1.5: 1$ yellow zone \\
\hline & & $>1.6: 1$ red zone \\
\hline
\end{tabular}

Source: (Jovičić \& Ilić, 2010)

To analyse the cultural indicators of sustainable development of tourism in Belgrade, statistical data on population 2011 was used, as well as data concerning accommodation capacities and tourist turnover in Belgrade in the period 2010-2019, recorded by the Statistical Office of the Republic of Serbia (Table 2). 
Table 2. CULTURAL INDICATORS OF SUSTAINABLE TOURISM DEVELOPMENT IN BELGRADE FOR THE PERIOD 2010-2019

\begin{tabular}{cccccc}
\hline Year & $\begin{array}{c}\text { Number of tourist } \\
\text { overnight stays } \\
\text { during } \text { year }\end{array}$ & Tourism intensity & Number of beds & $\begin{array}{c}\text { Ratio of } \\
\text { accommodation } \\
\text { capaties to the size } \\
\text { of the local } \\
\text { population }\end{array}$ & Zone \\
\hline 2010 & $1,319,629$ & 0.11 & 17,863 & 0.015 & Green \\
\hline 2011 & $1,337,199$ & 0.11 & 17,014 & 0.014 & Green \\
\hline 2012 & $1,431,384$ & 0.12 & 15,874 & 0.013 & Green \\
\hline 2013 & $1,489,801$ & 0.12 & 15,390 & 0.013 & Green \\
\hline 2014 & $1,535,341$ & 0.13 & 14,149 & 0.012 & Green \\
\hline 2015 & $1,686,017$ & 0.14 & 15,344 & 0.013 & Green \\
\hline 2016 & $1,867,150$ & 0.16 & 15,389 & 0.013 & Green \\
\hline 2017 & $2,190,474$ & 0.18 & 15,925 & 0.013 & Green \\
\hline 2018 & $2,480,516$ & 0.02 & 18,091 & 0.015 & Green \\
\hline 2019 & $2,696,832$ & 0.23 & 19,447 & 0.016 & Green \\
\hline
\end{tabular}

Source: (Gavrilović D, 2010, 2019)

The ratio of accommodation capacities to the size of the local population could be defined as favourable during the entire ten-year period since there was no intensive construction of tourist facilities. It can be noticed that there was a decrease in the number of beds during the time period 2010-2014, which began to increase again in 2015. The decrease in the number of beds could be explained as the result of the ownership transformation and privatisation of tourist and hospitality facilities, whereas the subsequent rise in the number of beds is related to the construction of accommodation capacities. However, regardless of the construction of tourist infrastructure and supra-structure in Belgrade, this cultural indicator is still in the green zone, indicating that the construction of tourist accommodation facilities has not yet become intensive. Tourism intensity is indicative of sustainable development of tourism since results obtained for all ten years belong in the green zone due to large number of people living in Belgrade as the capital of Serbia and no major influence of mass tourism. Such low tourism intensity has had a beneficial effect on the local environment and in order not to compromise it in the future, care should be taken to set a boundary between general and tourism zoning to serve the needs of domicile population. Furthermore, this indicator can show us that Belgrade has not been a fast-developing tourist destination and therefore has a relatively low level of tourist turnover compared to European metropolises.

\section{CONCLUSIONS AND DISCUSSION}

Cultural indicators of sustainable tourism development are subject to change since trends in the tourism market also vary considerably in real time, which can certainly be reflected in higher utilisation of capacities, an increase in the average length of stay in Belgrade and a reduction in seasonality of tourist visits. In addition to contributing to the theory of sustainable development of tourism, these results can have practical application in the territory of the City of Belgrade in terms of preserving the sustainability of development in the future. In that regard, it would be necessary to determine the carrying capacity of the destination to define the limits of permitted development. The concept of sustainable development of a tourist destination needs to be applied in Belgrade, as that is the only way in which both tourists and local residents can enjoy benefits of tourism. Benefits for the local population would be reflected in better traffic, eco-friendly urban landscaping and utilisation of renewable sources of energy, which would increase resources for new investments and development. In that regard, local businesspersons should be engaged in the tourism offer of the city, both directly and indirectly, 
which would stimulate the economic growth and create new job openings and better working conditions. Tourists, on the other hand, would enjoy a well-organised and clean city offering additional attractions that represent the history and culture of Belgrade in the best possible way. That would raise the quality of tourist attractions, improve tourism and transport infrastructure, ensure that Belgrade urban zones are cleaner and greener and most importantly, increase revenue and attract more tourists.

\section{REFERENCES}

Ceron, J. \& Dubois, G. (2003). Tourism and Sustainable Development Indicators: The Gap between Theoretical Demands and Practical Achievements. Current Issues in Tourism, 6(1), 54-75. DOI: $10.1080 / 13683500308667944$.

European Commission. (2016). The European Tourism Indicator System: ETIS toolkit for sustainable destination management. Luxemburg: Publications Office of the European Union.

Jovičić, D. (2000). Turizam i životna sredina: koncepcija održivog turizma. Beograd: Zadužbina Andrejević.

Jovičić, D. \& Ilić, T. (2010). Indikatori održivog turizma. Glasnik Srpskog geografskog društva, 42(1), 277-291. DOI: 10.2298/GSGD1001277J.

Ko, T.G. (2005). Development of a tourism sustainability assessment procedure: a conceptual approach. Tourism Management 26 (3), 431-445. https://doi.org/10.1016/j.tourman.2003.12.003.

Miller, G. (2001). The development of indicators for sustainable tourism: results of a Delphi survey of tourism researches. Tourism Management, 22, 351-362. DOI: 10.1016/S0261-5177(00)00067-4.

Panić, A. (2018). Planiranje odgovornog i održivog upravljanja turističkom destinacijom na primeru Beograda (magistarski rad). Brežice: Univerzitet u Mariboru, Fakultet za turizam.

Pavlović, S. \& Belij, M. (2012). Kulturni indikatori održivosti turizma u banjama Srbije. Glasnik Srpskoggeografskog društva 42(3), 95 - 108. DOI: 10.2298/GSGD1203095P.

Gavrilović, D. (2010, 2019). Statistical Yearbooks. Belgrade: Statistical Office of the Republic of Serbia.

Stojanović, V. (2006). Održivi razvoj turizma i životne sredine. Novi Sad: Departman za geografiju, turizam i hotelijerstvo. 